\title{
Permeation of Ionic Liquids through the skin
}

\author{
Permeação de Líquidos Iónicos através da pele
}

\author{
Ana Júlio1, Rita Caparica1, Joana Portugal Mota1, Maria Eduarda Araújo2, Catarina Rosado1, Tânia \\ Santos de Almeida1 \\ 1CBIOS-Research Center for Biosciences and Health Technologies, Lusófona University, Lisbon, Portugal. \\ 2Centro de Química e Bioquímica, Faculdade de Ciências, Universidade de Lisboa, Lisboa, Portugal \\ Email: tania.almeida@ulusofona.pt
}

\begin{abstract}
Alternative forms of drug delivery such as delivery through the skin, have been developed to explore other routes. However, the incorporation of poorly soluble or partially insoluble drugs into these delivery systems represents a major problem.

Ionic liquids (ILs) may be incorporated in aqueous, oily or hydroalcoholic solutions and thus, may be used as excipients in drug delivery systems to increase/improve the topical and transdermal drug delivery. However, it is fundamental to consider the cytotoxicity of these salts and it is also crucial to evaluate if these compounds permeate through the skin.

Herein, three imidazole-based ILs: [C2mim] $[\mathrm{Br}],[\mathrm{C} 4 \mathrm{mim}][\mathrm{Br}]$ and $[\mathrm{C} 6 \mathrm{mim}][\mathrm{Br}]$, were synthesized and each IL was incorporated within caffeine saturated solutions. Permeation studies of the active (caffeine) in these solutions were performed to evaluate the amount of IL that permeated through the porcine ear skin in the presence of the active. To achieve this, gravimetric studies of the receptor compartment were performed.

Results showed that the more lipophilic IL [C6mim][Br] presented the highest permeation through the skin. The permeation is dependent upon the size of the alkyl chain of the IL, and as more than $60 \%$ of the ILs permeate is it vital to consider the cytotoxicity of these salts when considering their incorporation in topical systems.
\end{abstract}

Keywords: Imidazole-based Ionic Liquids, caffeine solubility enhancement, ionic liquids permeation through the skin, lravimetric studies

\section{Resumo}

Têm sido desenvolvidas formas alternativas de veiculação de fármacos, como a veiculação através da pele, com o objetivo de explorar outras vias de administração. No entanto, a incorporação de fármacos pouco solúveis ou parcialmente insolúveis, nestes sistemas, representam um grande obstáculo.

Os líquidos iónicos (LI) podem ser incorporados em soluções aquosas, oleosas ou hidroalcoólicas, podendo ser usados como excipientes em sistemas de veiculação de fármacos para aumentar/melhorar a veiculação dos mesmos. Contudo, é fundamental considerar a citotoxicidade destes sais, bem como avaliar se estes permeiam a pele.

Neste âmbito, três LI derivados de imidazol, [C2mim][Br], [C4mim][Br] e [C6mim][Br], foram sintetizados e cada LI foi incorporado em soluções saturadas de cafeína. Foram realizados estudos de permeação do ativo nestas soluções, para avaliar a quantidade de LI que permeou através da pele de porco na presença do ativo. Para este efeito, realizaram-se estudos gravimétricos do compartimento recetor.

Os resultados mostraram que o LI mais lipofílico, [C6mim] [Br], foi o que apresentou maior permeação através da pele. Esta permeação depende do tamanho da cadeia alquilo do LI e mais de $60 \%$ destes LI permeiam, demonstrando que é fundamental considerar a citotoxicidade destes sais quando se pretende efetuar a sua incorporação em sistemas tópicos.

Palavras chave: Líquidos Iónicos de Imidazol; Aumento da Solubilidade da Cafeína; Permeação de Líquidos Iónicos na Pele de Porco; Estudos de gravimetria 


\section{Introduction}

Due to the technological advance by the pharmaceutical industry, new delivery systems have been developed and improved with the aim of making drug delivery more efficient [1]. Thus, since the route of administration has a significant impact on the therapy, some routes of administration, which until now were not relevant in drug delivery, began to have an additional importance [2]. In this context, the delivery of drugs through the skin has been one of the increasingly explored alternatives, especially topical delivery systems. These systems have numerous advantages compared to other delivery systems (oral and parenteral)[3] as it is a less painful and non-invasive choice, with more facilitated and convenient application, which allows for greater acceptance and adherence to therapy by the patient. This delivery system also allows the avoidance of the first pass effect and variations in gastric $\mathrm{pH}$, which gives it an additional advantage compared to other routes of administration, particularly the oral route $[4,5]$.

However, for the development of topical formulations, it is necessary to consider the drug that will be used and its applications, the excipients to be included, as well as the properties and characteristics of the skin, particularly the barrier property, conferred mainly by the extract corneum, [6] which limits the permeation of the drug and consequently its bioavailability. However, if this apparent skin limitation is a disadvantage in terms of therapy efficacy, the difficulty of certain excipients to permeate through the skin may on the other hand be an advantage to ensure a low incidence of side effects in topical systems. However, it is critical to assess the cytotoxicity of these ingredients, as well as the percentage of them that may permeate the skin.

Another challenge for the pharmaceutical industry is the low solubility of many drugs in water and in the organic solvents that can be safely used for solubilisation. Thus, one of the ways to overcome this complication is to develop functional excipients that may increase the solubility and incorporation of these poorly soluble drugs into developed delivery systems. In this context, ionic liquids (ILs) have been studied as promoters of solubility and permeation and some studies have shown the use of these materials for this purpose $[3,7,8,14,15]$. Ionic liquids are organic salts $[7,8]$, constituted by ions, an organic cation and an organic or inorganic anion $[7,9]$, which are liquid at temperatures below $100{ }^{\circ} \mathrm{C}$ $[10,11]$ or, in some cases, liquids at room temperature $[3,9]$. These compounds have several valuable properties, the ease of modification being the most relevant. Thus, it is possible to deliberately change the ions and

\section{Introdução}

Devido ao avanço tecnológico por parte da indústria farmacêutica, tem-se vindo a desenvolver e melhorar novos sistemas de veiculação com o objetivo de tornar mais eficiente a veiculação de fármacos[1] Desta forma, tendo em conta que a via de administração tem um impacto relevante na terapêutica, algumas vias de administração, que até aqui, não eram relevantes na veiculação de fármacos, começaram a ter uma importância adicional[2]. Neste âmbito, a veiculação de fármacos através da pele tem sido uma das alternativas vez mais exploradas, especialmente os sistemas de veiculação tópicos. Estes sistemas têm inúmeras vantagens comparativamente com outros sistemas de veiculação (oral e parenteral)[3] uma vez que são uma escolha menos dolorosa e não invasiva, onde a aplicação é mais facilitada e conveniente, o que permite uma maior aceitação e adesão à terapêutica por parte do paciente. Este sistema de veiculação permite ainda evitar o efeito de primeira passagem e as variações de $\mathrm{pH}$ gástrico, o que lhe confere uma vantagem adicional comparativamente com outras vias de administração, nomeadamente a via oral $[4,5]$ however do not greatly improve the permeation of drugs with molecular weights $>500 \mathrm{Da}$. In contrast active methods that normally involve physical or mechanical methods of enhancing delivery have been shown to be generally superior. Improved delivery has been shown for drugs of differing lipophilicity and molecular weight including proteins, peptides, and oligonucletides using electrical methods (iontophoresis, electroporation.

Para o desenvolvimento de formulações de aplicação tópica é necessário ter em conta o fármaco a utilizar e as suas aplicações, os excipientes a incluir, bem como as propriedades e características da pele, particularmente a propriedade barreira, conferida principalmente pelo estrato córneo[6], que limita a permeação do fármaco e, consequentemente, a sua biodisponibilidade. No entanto, se por um lado esta aparente limitação da pele constitui uma desvantagem quanto à eficácia da terapêutica, por outro lado a dificuldade de determinados compostos permearem através da pele pode ser uma vantagem para garantir uma baixa incidência de efeitos secundários em sistemas tópicos. No entanto, é fundamental avaliar a citotoxicidade destes ingredientes, bem como a percentagem dos mesmos que permeia a pele.

Outra problemática com que a área farmacêutica se depara, consiste na baixa solubilidade, de muitos dos fármacos, em água e nos solventes orgânicos que se podem utilizar. Assim, uma das formas de ultrapassar este obstáculo é a de desenvolver excipientes funcionais que 
to synthesize ILs with specific physical and chemical properties [3,7].

Currently, there are several studies that involve the incorporation of ILs into topical formulations, demonstrating that there is an impact of these salts on the solubility and permeation of poorly soluble active compounds [3,12-16]. However, there are few studies evaluating the functionality of these salts in non-cytotoxic percentages $[3,16]$, and to the best of our knowledge none consider to what extent these ionic liquids permeate the skin, which is relevant information when dealing with topical delivery systems. In this context, and as imidazole-based ionic liquids have been described has among the most toxic ILs in addition to being among the most studied, this study was intended to evaluate the amount of these ILs that permeate the skin in saturated solutions of a hydrophilic model drug, caffeine.

\section{Material and Methods}

\section{Materials and Reagents}

The reagents and solvents used (analytical grade) were acetone and anhydrous caffeine (Fagron, Spain), nitric acid (VWR, USA) and silver nitrate (Sigma-Aldrich, USA). Regarding the equipment, all weight measurements were done on an analytical weight Sartorius BP221S ${ }^{\circledR}$, (Sartorius AG, Germany), the oven used was a Memmert U30 ${ }^{\circledR}$ (Memmert, Germany) and the freezer was Omina $^{\circledR}$, (Omina, Spain). For the lyophilization, a freeze dryer labconco FreeZone $25^{\circledR}$, (Labconco, USA), was used. The filter paper used was a Qualitative Filter Paper, 413, diameter 150 mm, (VWR, France).

${ }^{1} \mathrm{H}$ NMR spectra obtained for confirmation of ILs structures were obtained on a Bruker Avance 400, (Bruker, USA). possam aumentar a solubilidade e incorporação destes fármacos, nos sistemas de veiculação desenvolvidos. Neste âmbito, os líquidos iónicos (LI) têm sido estudados como promotores de solubilidade e permeação e têm sido desenvolvidos alguns estudos que utilizam estes materiais com esta finalidade[3,7,8]. Os LI são sais orgânicos $[9,10]$, constituídos por iões, um catião orgânico e um anião orgânico ou inorgânico[9,11], que podem ser líquidos a temperaturas inferiores a 100 ${ }^{\circ} \mathrm{C}[12,13]$ ou, em alguns casos, líquidos à temperatura ambiente[3,11]. Estes compostos têm diversas propriedades valiosas, sendo a suscetibilidade a modificações a mais relevante. Assim, é possível alterar deliberadamente os iões que os constituem e sintetizar LI com propriedades físicas e químicas específicas[3,9].

Atualmente, são diversos os estudos, que envolvem a incorporação de LI em formulações tópicas, demonstrando que existe um impacto destes sais na solubilidade e permeação de compostos ativos pouco solúveis[3,7,8,14,15]. No entanto, são poucos os estudos que avaliam a funcionalidade destes sais em percentagens não citotóxicas $[3,16]$, e tanto quanto sabemos nenhum considera quanto destes líquidos iónicos permeiam a pele, informação relevante quando se pretende uma aplicação em sistemas de veiculação tópicos. Neste âmbito, e uma vez que os líquidos iónicos derivados de imidazol além de estarem entre os mais estudados estão também descritos como sendo dos mais tóxicos, pretendeu-se no âmbito deste trabalho avaliar que quantidade destes LI permeia a pele em soluções saturadas de um activo modelo hidrofílico, a cafeína.

\section{Material e Métodos}

\section{Material e Reagentes}

Os reagentes e solventes usados, de grau analítico, foram a Acetona, a Cafeína anidra de Fagron, Espanha, o Ácido nítrico de VWR, Estados Unidos da América (EUA) e o Nitrato de Prata de Sigma-Aldrich, EUA. No que diz respeito aos equipamentos, todas as pesagens foram realizadas numa balança analítica Sartorius $\mathrm{BP} 221 \mathrm{~S}^{\circledR}$,(Sartorius $\mathrm{AG}$, Alemanha), já a estufa é Memmert U30 ${ }^{\circledR}$, (Memmert, Alemanha) e o frigorífico da Omina ${ }^{\circledR},($ Omina, Spain). Para o processo de liofilização utilizou-se um liofilizador LABCONCO FreeZone $25^{\circledR}$, (Labconco, EUA).

Os espectros de ${ }^{1} \mathrm{H}$ RMN obtidos para a confirmação da síntese dos LI foram obtidos num aparelho Brucker Avance 400, (Bruker, EUA). O papel de filtro usado é o papel qualitativo 413, com um diâmetro de $150 \mathrm{~mm}$, (VWR, França). 


\section{Methods}

\section{Synthesis of ILs}

In this study, three imidazole-based ILs were prepared, 1-Ethyl-3-methylimidazolium bromide [C2mim][Br], 1-Butyl-3-methylimidazolium bromide [C4mim][Br] and 1-Hexyl-3-methylimidazolium, according to the literature $[16,17]$. The ILs were characterized by ${ }^{1} \mathrm{H}$ NMR spectra in a Bruker Advance 400 apparatus at 400 $\mathrm{MHz}$, using $\mathrm{D}_{2} \mathrm{O}, \mathrm{CDCl}_{3}$ or DMSO-d6 as solvents.

\section{Permeation study}

Permeation studies $(n=5)$ were performed on vertical diffusion glass cells (Franz cells) with a receiver volume of approximately $4 \mathrm{~mL}$ and a diffusion area of $0.95 \mathrm{~cm}^{2}$, using porcine ear skin, kindly provided from Suinimais Lda, Leiria, Portugal.

The porcine ear skin was harvested immediately after the animals were sacrificed and washed with cold water. Any damaged skin was discarded. The skin samples were separated from the cartilage, being careful not to damage the skin, and stored in the freezer at $-4{ }^{\circ} \mathrm{C}$ until used, for a period not exceeding six weeks. At the time of the study, the sample was thawed and cut to the required size to place in the Franz cell [3].

In the donor compartment were placed $500 \mu \mathrm{L}$ of saturated solution of caffeine in a water:IL mixture (95:5). This compartment was then occluded by sealing it with microscope coverslips. Phosphate buffer $\mathrm{pH} 7.4$ (USP 32) was placed in the receptor compartment, and this compartment was immersed in a thermostatic bath at 37 ${ }^{\circ} \mathrm{C}$ to ensure that the skin was at $32{ }^{\circ} \mathrm{C}$.

At predetermined time intervals, the entire medium was collected in the receptor compartment and then replaced with previously heated, at $37{ }^{\circ} \mathrm{C}$, fresh medium. Immediately following collection, the samples were frozen at $-40{ }^{\circ} \mathrm{C}$ in glass flasks. All collected samples were simultaneously freeze-dried at $-45^{\circ} \mathrm{c}, 400 \mathrm{mTorr}$ for 24 hours.

Gravimetric studies: Evaluation of the percentage of imidazole-based ILs that permeated the skin

To quantify the amount of halogenated ILs contained in caffeine saturated solutions that permeated the porcine ear skin, gravimetric studies of the lyophilized samples collected from the receptor compartment were performed.

The assay was done in triplicate and $0.03 \mathrm{~g}$ of the lyophilized samples were weighed. Then, $13.5 \mathrm{~mL}$ of water and $0.075 \mathrm{~mL}$ of aqueous solution of $6 \mathrm{M}$ nitric acid were added. This solution was stirred and $4.5 \mathrm{~mL}$ of an aqueous solution of $0.125 \mathrm{M}$ silver nitrate was then

\section{Métodos}

\section{Síntese dos LI}

No âmbito deste estudo foram sintetizados três LI derivados de imidazol, nomeadamente o Brometo de 1-etil-3-metilimidazólio [C2mim][Br], o Brometo de 1-butil-3-metilimidazólio [C4mim][Br] e o Brometo de 1-hexil-3-metilidazólio [C6mim][Br], de acordo com a literatura $[16,17]$. Os compostos foram caracterizados por ${ }^{1} \mathrm{H}$ RMN no Brucker Avance 400, a $400 \mathrm{MHz}$, usando $\mathrm{D}_{2} \mathrm{O}, \mathrm{CDCl}_{3}$ ou DMSO-d6 como solventes.

\section{Estudo de Permeação}

Os estudos de permeação $(\mathrm{n}=5)$ foram realizados em células de vidro de difusão vertical (células de Franz) com um volume recetor de, aproximadamente, $4 \mathrm{~mL}$ e uma área de difusão de $0,95 \mathrm{~cm}^{2}$, usando pele de orelha de porco, cedida gentilmente pela Suinimais Lda, Leiria, Portugal.

A pele de orelha de porco foi colhida, imediatamente, após o sacrifício dos animais, sendo depois levada com água fria e rejeitadas as zonas que se encontravam danificadas. As amostras de pele foram separadas da cartilagem, com cuidado para que não existisse danificação das mesmas, e armazenadas no congelador a $-4{ }^{\circ} \mathrm{C}$ até serem usadas, não excedendo um período superior a 6 semanas. No momento do estudo, a amostra foi descongelada e cortada do tamanho necessário para colocar na célula de Franz [3].

No compartimento dador foram colocados $500 \mu \mathrm{L}$ da solução saturada de cafeína numa mistura de água:LI (95:5), este compartimento foi tapado por uma lamela de microscópio. Já no compartimento recetor foi colocado tampão fosfato $\mathrm{pH} 7,4$ (USP 32), ficando depois este compartimento mergulhado num banho termostatizado a $37{ }^{\circ} \mathrm{C}$, de forma a garantir que a pele se encontra a $32{ }^{\circ} \mathrm{C}$.

Em intervalos de tempo pré-determinados, foi efetuada a recolha total do meio existente no compartimento recetor, procedendo-se, de seguida, à reposição do mesmo com meio fresco previamente aquecido a $37{ }^{\circ} \mathrm{C}$. As amostras recolhidas nos intervalos pré-determinados do ensaio de permeação foram congeladas a $-40{ }^{\circ} \mathrm{C}$ (Deep Freezer VXE 490, Jouan SA, República Checa) em recipientes de vidro. De seguida, procedeu-se à liofilização de todas as formulações, tendo-se realizado o processo de secagem do solvente, água, a $-45{ }^{\circ} \mathrm{C}$ e 400 mTorr durante $24 \mathrm{~h}$.

Estudos de Gravimetria:_Avaliação da percentagem de LI que permeia a pele

Para quantificar a quantidade de LI, contida em soluções saturadas de cafeína, que permearam a pele de 
added. Next, the solution was gently warmed at $35{ }^{\circ} \mathrm{C}$ and then cooled to RT, followed by gravity filtration, with a previously weighed fluted paper filter. The paper filter was washed with two $0.75 \mathrm{~mL}$ portions of water and three $0.75 \mathrm{~mL}$ portions of acetone. Then, the paper filter paper was placed to dry in the oven at $60^{\circ} \mathrm{C}$ overnight and subsequently placed in the desiccator. The quantification of the sample was carried out with the successive daily weighing of the solid mass, which was retained in the paper filter, until three equal consecutive weights were obtained[18].

\section{$\underline{\text { Statistical Analysis }}$}

Differences in mean values of the results were evaluated by one-way analysis of variance, ANOVA, followed by Tukey's multiple comparison test. Values were expressed as mean \pm standard deviation, SD. The differences between individual means were significant at $*$ $\mathrm{p}<0.05, * * \mathrm{p}<0.01$ and $* * * \mathrm{p}<0.001$.

All analyses were performed using GraphPad Prism $5^{\circledR}$ by GraphPad Software, USA.

\section{Results and Discussion}

Previous studies have shown that imidazole-based ILs can be used to enhance drug solubility and permeation [3]. However, these ILs have a higher cytotoxicity profile $[3,19]$ when compared to ILs containing other cations in their constitution, such as choline-based ILs [3], and thus it becomes relevant to understand if they permeate the skin.

In this context, three imidazole-based ILs, [C2mim] $[\mathrm{Br}],[\mathrm{C} 4 \mathrm{mim}][\mathrm{Br}]$ and $[\mathrm{C} 6 \mathrm{mim}][\mathrm{Br}]$, were synthesized, according to the techniques described in the literature $[16,17]$ and their structures were confirmed by ${ }^{1} \mathrm{H}-\mathrm{NMR}$.. Then, permeation studies of saturated solutions of caffeine containing $5 \%$ of each studied IL were conducted. Gravimetric studies of the collected and lyophilized samples in the receptor compartment were then carried out. The results of caffeine permeation in the presence and absence of ILs (Figure 1) agreed with previously published results [3]. Particularly, it was possible to confirm that in the presence of IL, there is an porco, foram realizados estudos gravimétricos das amostras recolhidas no compartimento do recetor e posteriormente liofilizadas.

O ensaio foi feito em triplicado e foi pesada uma massa de amostra de 0,03 g. Em seguida, foram adicionados $13,5 \mathrm{~mL}$ de água desionizada e $0,075 \mathrm{~mL}$ de solução aquosa de ácido nítrico $6 \mathrm{M}$. Esta solução foi agitada e foram acrescentados 4,5 mL de uma solução aquosa de nitrato de prata $0,125 \mathrm{M}$. Posteriormente, a solução foi suavemente aquecida a $35^{\circ} \mathrm{C}$, sendo depois arrefecida até à temperatura ambiente, seguida de filtração gravimétrica, com um filtro de papel previamente pesado. $\mathrm{O}$ filtro de papel foi lavado com duas porções de $0,75 \mathrm{~mL}$ de água desionizada e três porções de $0,75 \mathrm{~mL}$ de acetona. De seguida, o papel de filtro foi colocado para secar na estufa a $60{ }^{\circ} \mathrm{C}$ durante uma noite e posteriormente colocado no exsicador. A quantificação da amostra foi realizada com a pesagem diária sucessiva da massa sólida, que ficou retida no filtro de papel, até à obtenção de três pesos iguais consecutivos [18].

Análise Estatística

As diferenças na média dos resultados foram avaliadas por análise de variância unidirecional, ANOVA, seguida do teste de comparação múltipla de Tukey. Os valores foram expressos como média \pm desvio padrão, DP. As diferenças foram significantes com $* \mathrm{p}<0,05, * * \mathrm{p}$ $<0,01 \mathrm{e}^{* * *} \mathrm{p}<0,001$.

Todas as análises foram realizadas usando o GraphPad Prism $5^{\circledR}$ pelo GraphPad Software, EUA.

\section{Resultados e Discussão}

Estudos anteriores demonstraram que os LI derivados de imidazol podem ser utilizados como promotores da solubilidade e permeação de ativos [3]. No entanto, estes LI apresentam um perfil de citotoxicidade mais elevado[3,19], quando comparados com LI contendo outros catiões na sua constituição, nomeadamente os derivados da colina[3], pelo que se torna relevante compreender a sua capacidade de permeação cutânea. Neste âmbito, três LI derivados de imidazol, o [C2mim] $[\mathrm{Br}]$, o $[\mathrm{C} 4 \mathrm{mim}][\mathrm{Br}]$ e o $[\mathrm{C} 6 \mathrm{mim}][\mathrm{Br}]$ foram sintetizados de acordo com as técnicas descritas na literatura $[16,17]$ e as suas estruturas confirmadas por ${ }^{1} \mathrm{H}-\mathrm{RMN}$ no Brucker Avance 400, a $400 \mathrm{MHz}$, usando $\mathrm{D}_{2} \mathrm{O}$ ou $\mathrm{CDCl}_{3}$ como solventes (dados não apresentados). Seguidamente, foram executados estudos de permeação de soluções saturadas de cafeína cada uma contendo $5 \%$ de um dos três LI estudados e posteriormente foram efetuados estudos gravimétricos das amostras recolhidas e liofilizadas do compartimento recetor. Re- 
increase in the caffeine permeation and that parameter increases with the increase of the alkyl chain length of IL (Figure 1). These results have already been justified as being due to an increase in the diffusion of the active through the skin and/or to an increase in the partition coefficient of caffeine, since the increase of the hydrophobicity of the vehicle, because of the increase of the alkyl chain, increases the hydrophilic substance partition [3]. Since permeation results demonstrated that the increase of the alkyl chain of ILs influences the permeation of caffeine, it becomes even more relevant to assess whether this structural difference in the composition of the ILs may influence its own permeation through the skin. lativamente aos resultados da permeação da cafeína na presença e ausência dos LI estudados (Figura 1), estes encontram-se de acordo com os resultados previamente publicados [3]. Nomeadamente, foi possível comprovar que na presença dos LI há um aumento da permeação da cafeína e que esta permeação aumenta com o aumento da cadeia de alquilo do LI (Figura 1). Estes resultados já foram justificados como devendo-se a um aumento da difusão do ativo através da pele e/ou a um aumento no coeficiente de partilha da cafeína, uma vez que o aumento da hidrofobicidade do veículo, em consequência do aumento da cadeia, aumenta a partilha do ativo hidrofílico [3]. Uma vez que os resultados da permeação demonstram que o aumento da cadeia de alquilo dos LI tem efeitos na permeação do ativo modelo estudado, torna-se ainda mais relevante avaliar se esta diferença estrutural dos três LI pode influenciar a sua própria permeação através da pele.

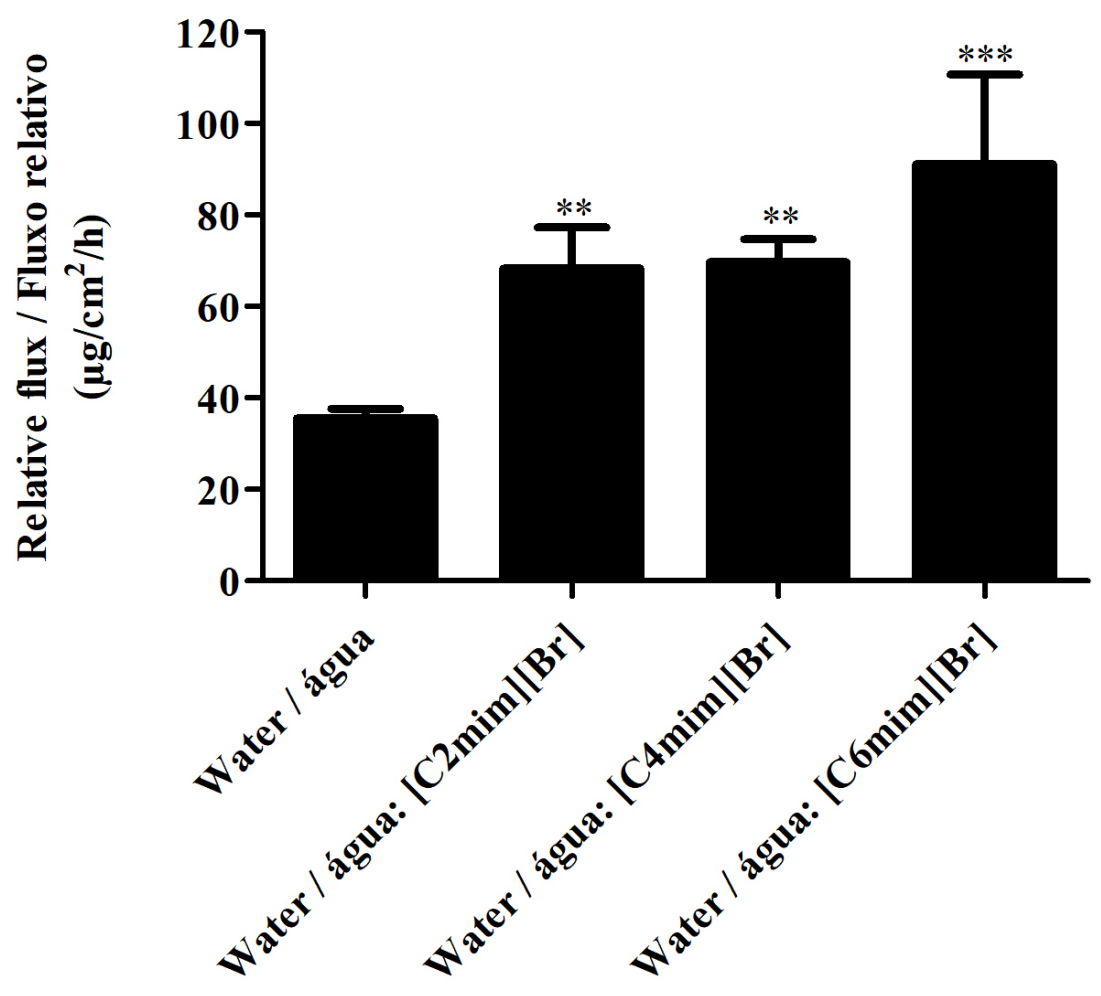

Figure 1/ Figura 1- Relative permeation flux of saturated solutions of caffeine in water or in water:IL mixtures, 95:5 \% w/w. $n=5$, mean \pm SD and $* * p<0.01$ and $* * * p<0.001$ with ANOVA, Tukey's test.

Fluxo relativo da permeação de soluções saturadas de cafeina em água ou mistura água:LI, 95:5\% $(\mathrm{m} / \mathrm{m}) . \mathrm{n}=5$, média $\pm \mathrm{DP} \mathrm{e}^{* *} \mathrm{p}<0.01 \mathrm{e} * * * \mathrm{p}<0.001 \mathrm{com}$ ANOVA, teste de Tukey. 
Effectively, the results of the gravimetric study (Figures 2 and 3) showed that [C6mim] [Br], the most lipophilic IL, presented the highest permeation through the skin. The results also showed, once again, that the higher the alkyl chain, the higher the percentage of IL that permeates the skin, as was observed for the studied drug. This fact may be due to a better surfactant ability of the IL, because of the increase in the alkyl chain, leading to increased skin instability and, thus, promoting the not only the drug permeation but also IL permeation. It is known that surfactants are classical permeation promoters, causing disorganization of the ceramides bilayers of the stratum corneum [20]. It should also be mentioned that for the most toxic ILs $[\mathrm{C} 4 \mathrm{mim}][\mathrm{Br}]$ and $[\mathrm{C} 6 \mathrm{mim}][\mathrm{Br}]$, permeation percentage is quite high, above $80 \%$, which demonstrates how imperative it is to consider the cytotoxicity of these salts when considering their use as functional ingredients in topical delivery systems, since most of these IL will permeate the skin.
Efetivamente, os resultados do estudo gravimétrico (Figura 2 e 3) realizado neste estudo mostraram que o [C6mim][Br], o LI mais lipofílico, apresentou uma maior permeação através da pele. Os resultados também mostraram, mais uma vez, que quanto maior a cadeia de alquilo, maior a percentagem de LI que permeia a pele, à semelhança do que se observou para o ativo estudado. Este facto pode dever-se a uma melhor capacidade surfactante do LI, em consequência do aumento da cadeia de alquilo, provocando uma maior instabilidade na pele e, promovendo assim, não só a permeação do ativo mas também a permeação dos LI. É sabido que os surfactantes são promotores da permeação clássicos, causando desorganização das bicamadas de ceramidas do estrato córneo[20]. Deve ainda ser mencionado que, para os LI mais tóxicos, o [C4mim][Br] e o [C6mim] [Br], a percentagem de permeação é bastante elevada, acima dos $80 \%$, o que demonstra o quão imperativo é considerar os seus resultados de citotoxicidade aquando do seu uso como ingredientes funcionais em sistemas de veiculação tópicos, dado que a maioria do conteúdo destes LI permeará a pele.

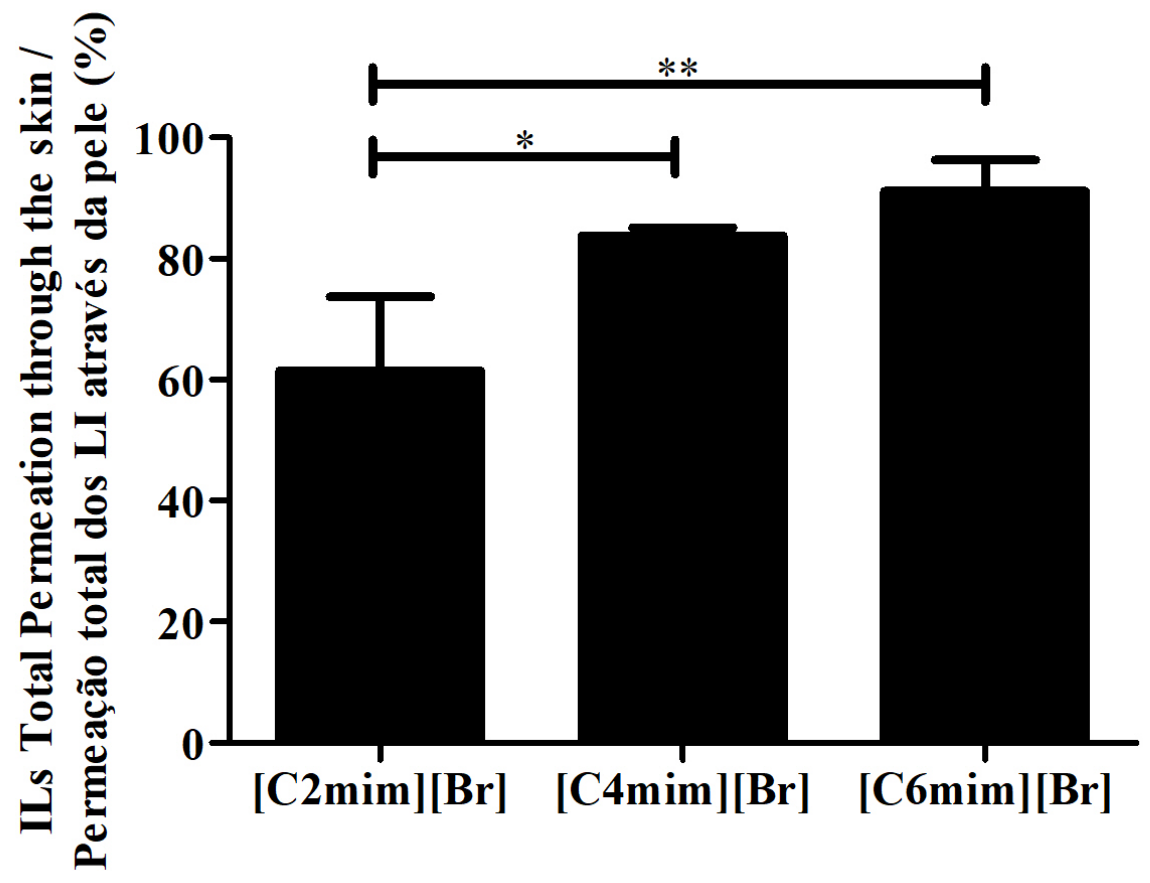

Figure 2/Figura 2: Percentage of ILs total permeation through the skin (\%), at the end of six hours. $n=3$, mean \pm SD and $* p<0.05$ and $* * * p<0.01$ with ANOVA, Tukey's test.

Percentagem da permeação total dos LI através da pele (\%), ao fim 6 horas. $n=3$, média \pm DP e e $^{*}<0.05 \mathrm{e}^{* *} \mathrm{p}<0.01$ com ANOVA, teste de Tukey. 


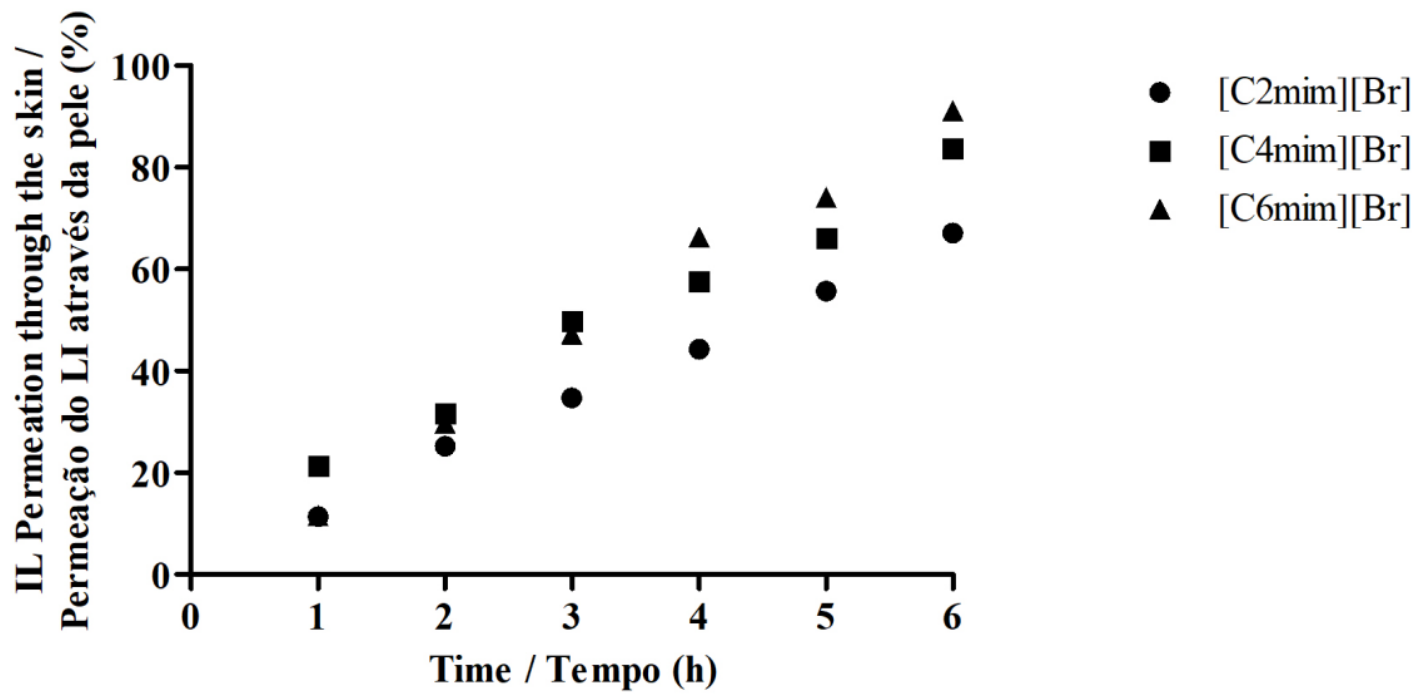

Figure 3/ Figura 3 - Ionic Liquids permeation through the skin (\%) in caffeine saturated solutions over six hours, in water:IL mixtures, 95:5 (w/w) Permeação dos Líquidos iónicos através da pele (\%), ao longo de $6 \mathrm{~h}$, em soluções saturadas de cafeina em misturas água:LI, 95:5\% (m/m).

\section{Conclusion}

Three imidazole-based ILs were prepared - [C2mim] $[\mathrm{Br}],[\mathrm{C} 4 \mathrm{mim}][\mathrm{Br}]$ and $[\mathrm{C} 6 \mathrm{mim}][\mathrm{Br}]$-and each were incorporated in caffeine saturated solutions and permeation studies using pig ear skin were performed. Results for caffeine permeation in the presence of the studied ILs agreed with previously published results, showing that the ILs enhance caffeine solubility and that the more lipophilic IL, [C6mim] [Br], is the best solubility promoter. More importantly, the amount of ILs that permeated through the skin was evaluated through gravimetric studies, since in topical systems, this information may be crucial when deciding the amount of these ingredients that may effectively be used. In this context, gravimetric results showed that a high percentage of these ILs $(>60 \%)$ permeates through the skin and that this permeation is dependent on the size of alkyl chain of the ILs.

\section{Conclusão}

No âmbito deste estudo foram preparados três LI derivados de imidazol, [C2mim][Br], [C4mim][Br] e [C6mim][Br]. Todos os LI preparados foram incorporados em soluções saturadas de cafeína e foram realizados estudos de permeação em pele de orelha de porco. Os resultados para a permeação da cafeína na presença dos LI estudados estão de acordo com resultados publicados anteriormente, e mostram que os LI aumentam a solubilidade da cafeína, sendo o LI mais lipofílico, o [C6mim] $[\mathrm{Br}]$, o melhor promotor da solubilidade. De salientar ainda que, no âmbito deste estudo se determinou a quantidade de LI que permeou através da pele, uma vez que, nos sistemas de veiculação tópicos, esta informação pode ser crucial quando se pretende decidir que quantidade desses ingredientes pode efetivamente ser utilizada. Neste contexto, foram executados estudos gravimétricos que demonstraram que uma elevada percentagem dos LI estudados permeia a pele $(>60 \%)$ e que esta permeação depende do tamanho da cadeia de alquilo dos mesmos. 


\section{Acknowledgments}

This work was financially supported by Fundação para a Ciência e a Tecnologia (FCT, Portugal), through funding UID/DTP/04567/2016 to CBIOS. Part of the work was also supported by FCT to CQB through project UID/MULTI/00612/2013. Ana Júlio acknowledges his research grant attributed in the scope of the project UID/DTP/04567/2016.

\section{Conflict of Interests}

The authors declare there are not financial and/or personal relationship that may present potential conflict of interest.

\section{Agradecimentos}

Este trabalho foi financiado por fundos nacionais através da FCT - Fundação para a Ciência e a Tecnologia, I.P., no âmbito do projeto UID/DTP/04567/2016 atribuído ao CBIOS. Parte do trabalho foi ainda financiado pela FCT ao CQB através do projecto UID/ MULTI/00612/2013. Ana Júlio agradece a bolsa de investigação concedida no âmbito do projeto UID/ DTP/04567/2016.

\section{Conflito de Interesses}

Os autores declaram que não há relações financeiras e/ ou pessoais que possam representar potencial conflito de interesses.

\section{References/Referências}

1. Singh Malik D, Mital N, Kaur G. Topical drug delivery systems: a patent review. Expert Opin. Ther. Pat. 2013; 26(2):213-28.

2. Jitendra, Sharma PK, Bansal S, Banik A. Noninvasive routes of proteins and peptides drug delivery. Indian J. Pharm. Sci. 2011; 73(4):367-75.

3. Santos de Almeida T, Júlio A, Saraiva N, et al. Choline- versus imidazole-based ionic liquids as functional ingredients in topical delivery systems: cytotoxicity, solubility, and skin permeation studies. Drug Dev. Ind. Pharm. 2017; 43(11):1858-65.

4. Brown MB, Martin GP, Jones S a, Akomeah FK. Dermal and transdermal drug delivery systems: current and future prospects. Drug Deliv. 2006; 13(May 2005):175-87.

5. Torin Huzil J, Sivaloganathan S, Kohandel M, Foldvari M. Drug delivery through the skin: Molecular simulations of barrier lipids to design more effective noninvasive dermal and transdermal delivery systems for small molecules, biologics, and cosmetics. Wiley Interdiscip. Rev. Nanomedicine Nanobiotechnology. 2011; 3(5):449-62.

6. Heylings JR. Transdermal and Topical Drug Delivery, Wiley, 2012.

7. Frizzo CP, Gindri IM, Tier AZ, Buriol L, Moreira DN, Martins MAP. Pharmaceutical Salts : Solids to Liquids by Using Ionic Liquid Design. In: Ionic Liquids-New Aspects for the Future. 2013; 557-580.

8. Mizuuchi H, Jaitely V, Murdan S, Florence AT. Room temperature ionic liquids and their mixtures: Potential pharmaceutical solvents. Eur. J. Pharm. Sci. 2008; 33(4-5):326-31.

9. Dobler D, Schmidts T, Klingenhoefer I, Runkel F. Ionic liquids as ingredients in topical drug delivery systems. Int. J. Pharm. 2012; 441(1-2):620-27.

10. Ferraz R, Branco LC, Prudêncio C, Noronha JP, Petrovski Ž. Ionic liquids as active pharmaceutical ingredients. Chem Med Chem. $2011 ; 6(6): 975-85$.

11. Gouveia W, Jorge TF, Martins S, et al. Toxicity of ionic liquids prepared from biomaterials. Chemosphere. 2014; 104:51-6.

12. Balk A, Holzgrabe U, Meinel L. Pro et contra' ionic liquid drugs - Challenges and opportunities for pharmaceutical translation. Eur. J. Pharm. Biopharm. 2015; 94(June):291-304.

13. Almeida TS de, Júlio A, Mota JP, Rijo P, Reis CP. An emerging integration between ionic liquids ans nonotechnology: general uses and future prospects in drug delivery. Ther. Deliv. 2017; 6(8):461-73.

14. Frade RF, Afonso CA. Impact of ionic liquids in environment and humans: an overview. Hum. Exp. Toxicol. 2010; 29(12):1038-54.

15. Hough WL, Smiglak M, Rodríguez H, et al. The third evolution of ionic liquids: active pharmaceutical ingredients. New J. Chem. $2007 ; 31(8): 1429-36$.

16. Czekanski L, Santos de Almeida T, Portugal Mota J, Rijo P, Araújo MEM. Synthesis of benzoazole ionic liquids and evaluation of their antimicrobial activity. Biomed. Biopharm. Res. 2014; 11(2):227-35.

17. Gouveia W, Jorge TF, Martins S, et al. Toxicity of ionic liquids prepared from biomaterials. Chemosphere. 2014; 104:51-6.

18. Nelson J. Chemistry: The Central Science. Prentice-Hall, 3th ed, 1985.

19. Santos de Almeida T, Júlio A, Caparica R, et al. Ionic liquids as solubility/permeation enhancers for topical formulations: Skin permeation and cytotoxicity characterization. Toxicol. Lett. 2015.

20. Ahad A, Aqil M, Kohli K, et al. Chemical penetration enhancers: a patent review. Expert Opin. Ther. Pat. 2009; 19(7):969-88. 